\title{
Maintenance status of $\mathrm{N95}$ respirator masks after use in a health care setting
}

\author{
ESTADO DE CONSERVAÇÃO DE RESPIRADORES PFF-2 APÓS USO NA ROTINA \\ HOSPITALAR
}

ESTADO DE CONSERVACIÓN DE RESPIRADORES PFF-2 DESPUÉS DE SU USO
EN LA RUTINA HOSPITALARIA

\section{Laura Regina Parreira Duarte ${ }^{1}$, Claudio Eduardo Miola², Nilton José Fernandes Cavalcante ${ }^{3}$, Ricardo Helbert Bammann ${ }^{4}$}

\begin{abstract}
With the purpose of assessing the damages to $\mathrm{N} 95$ respirator masks over time and to estimate their expiration after use in clinical practice, this study was based on the descriptive analysis of N95 cone-shaped masks collected by nursing assistants after one, five, 15, and 30 consecutive days of use. Personal identification marks were founds in every respirator already on the first day of use. From the fifth day onward, all masks presented some type of dirt while folds were observed in more than $80 \%$ of the devices. Internal stains and folds were more frequent among workers of the 12 hour shift in comparison to the 6-hour shift $(p<0.05)$. The percentage of misplaced respirators was $16.17 \%$ by day five and reached $38.93 \%$ by day thirty. Though there is no convenience in reusing N95 respirators, their expiration should not exceed 5 days of use.
\end{abstract}

\section{KEY WORDS}

Occupational health.

Respiratory protective devices.

Tuberculosis.

Protective devices.

\begin{abstract}
RESUMO
Visando quantificar os danos impostos a respiradores PFF-2 ao longo do tempo de uso e estimar seu período de validade na prática clínica, este estudo baseou-se na análise descritiva de máscaras cônicas do tipo PFF-2, coletadas por auxiliares de enfermagem após um, cinco, 15 e 30 dias consecutivos de uso, num hospital de referência para doenças infecciosas. Marcas de identificação pessoal foram encontradas em todos os respiradores já no primeiro dia de uso. A partir do quinto dia, todas as máscaras apresentavam sujeiras, enquanto dobraduras foram observadas em mais de $80 \%$ dos equipamentos. Manchas internas e dobras foram mais freqüentes após turnos de 12 horas do que plantões de 6 horas ( $p<0.05$ ). 16,17\% das máscaras estavam extraviadas no quinto dia e $38.93 \%$ após o 30 ㅇa dia de uso. O prazo de validade do respirador PFF-2, embora não seja conveniente reutilizá-lo, deve se limitar a cinco dias.
\end{abstract}

\section{DESCRITORES}

Saúde do trabalhador.

Dispositivos de proteção respiratória.

Tuberculose.

Equipamentos de proteção.

\section{RESUMEN}

En la intención de cuantificar los daños impuestos a respiradores PFF-2 a lo largo del tiempo de uso y estimar su vida útil en la práctica clínica, este estudio se basó en el análisis descriptivo de máscaras cónicas del tipo PFF-2 revisadas después de uno, cinco, quince y treinta días consecutivos de uso por auxiliares de enfermería en un hospital de referencia para enfermedades infecciosas. Ya en el primer día de uso fueron encontradas marcas de identificación personal en todos los respiradores. A partir del quinto día, todas las máscaras presentaban suciedad, mientras que fueron observados pliegues en más del $80 \%$ de los equipos. Las manchas internas y pliegues fueron más frecuentes luego de turnos de 12 horas que de guardias de 6 horas $(p<0,05) .16,17 \%$ de las máscaras habían sido extraviadas hacia el quinto día, y $38,93 \%$ luego del trigésimo día de uso. El tiempo de validez del respirador PFF-2, aunque no sea conveniente reutilizarlo, debe limitarse a cinco días.

\section{DESCRIPTORES}

Salud laboral.

Dispositivos de protección respiratória. Tuberculosis.

Equipos de seguridad.

\footnotetext{
* Taken from the thesis "Maintenance status of N95 respirators after use by nursing assistants", Graduate Program, Coordenadoria de Controle de Doenças, São Paulo State Health Secretary, 2006. ${ }^{1}$ M.Sc. in Health Sciences. Nurse, Instituto de Infectologia Emílio Ribas. São Paulo, SP, Brazil. duartela@terra.com.br ${ }^{2}$ Ph.D. in Health Sciences. Nurse, Instituto de Infectologia Emílio Ribas. São Paulo, SP, Brazil. cemio@uol.com.br ${ }^{3} \mathrm{Ph} . \mathrm{D}$. in Medicine. Physician, Instituto de Infectologia Emílio Ribas. Faculty and Advisor, Graduate Program, Coordenadoria de Controle de Doenças, São Paulo State Health Secretary. São Paulo, SP, Brazil. paiva.cavalcante@terra.com.br ${ }^{4}$ Ph.D. in Medicine. Physician, Instituto de Infectologia Emílio Ribas. Faculty and Advisor, Graduate Program, Coordenadoria de Controle de Doenças, São Paulo State Health Secretary. São Paulo, SP, Brazil. ricbammann@uol.com.br
}

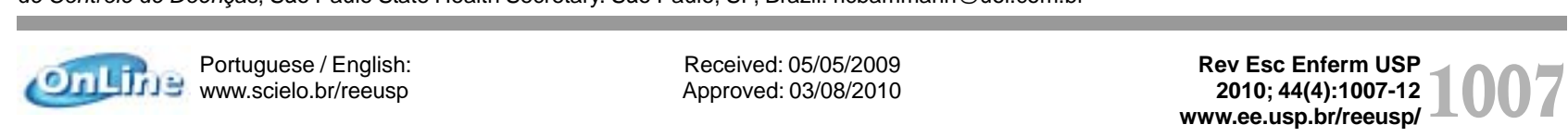




\section{INTRODUCTION}

Masks and respirators are the main individual protection equipment (IPE) in the context of respiratory illnesses, including tuberculosis (TB). The N95 respirator (which health authorities call PFF-2 in Brazil) is the indicated IPE for TB prevention. In the United States, the National Institute for Occupational Safety and Health (NIOSH) approved its use as early as in $1995^{(1-3)}$.

In Brazil, the use of IPE is regulated by the Ministry of Labor $^{(4)}$, which rules, among others, that companies are obliged to freely provide their employees with appropriate IPE in good usage conditions whenever collective measures do not offer full protection against accident risks or occupational illnesses. IPE should be used solely for its specific purpose, and employees are responsible for its maintenance; they should also inform employees on any alteration or damage that implies the IPE's inadequacy for use ${ }^{(4)}$.

According to the American Centers for Disease Control and Prevention $(C D C)^{(1)}$ and $\mathrm{N} 95$ respirator manufacturers ${ }^{(5)}$, these devices can function for weeks and, hence, the same worker can reuse them. The respirators should only be replaced if they do no longer adapt to the user's face, if they are dirty due to body fluids or in case of evident structural damage. These definitions, however, are too generic damage has never been quantified and there is no clear and precise recommendation as to usage time limits.

The user may not perceive structural damage and compromised performance of the respirator, which in turn can mean decreased protection. Deteriorated efficiency of the filtering material, fitting capacity and maintenance and storage of the IPE after use are the main factors that need to be taken into account whenever discardable respirators and masks are reused ${ }^{(6)}$.

\section{OBJECTIVE}

This research aimed to describe visible structural damage in N95 respirators after use by nursing assistants, as well as to assess their conditions and preservation across the usage time, thus estimating their validity in routine clinical practice.

\section{METHOD}

A descriptive, prospective and longitudinal observational study was carried out between May and August 2005, based on the standardized observation of N95 respirator conditions collected after use by nursing assistants.

The Instituto de Infectologia Emilio Ribas (IIER) is a teaching hospital that is part of the state public network in São Paulo city. It offers approximately 200 beds, exclusively for infectiouscontagious diseases, especially HIV patients. About 800 health professionals work direct or indirectly in daily and close contact with a large number of patients with a suspected diagnosis of pulmonary TB, besides some other patients with confirmed TB, including cases of multi-resistant TB. Since 1996, administrative routine at the IIER has included the monthly distribution of a discardable N95 respirator for each nursing professional working at the hospital (including temporary and permanent contracts, trainees, day and night shifts etc.).

All nursing assistants at the IIER were invited to participate in the study, during the three work shifts (morning, afternoon and night). Professionals were only included if they voluntarily agreed to participate (by signing the Free and Informed Consent Term) and worked in direct care delivery to patients. The final study sample comprised 167 $(66.54 \%)$ of the 251 nursing assistants active at the hospitalization units/nursing wards.

Participants received an N95 respirator at the start of their shift when the study began, following the above described institutional routine. The IPE used in this research was manufactured and supplied by $3 \mathrm{M}$ do Brasil Ltda. The same (cone-shaped) model and brand were used as the IIER purchased (IIER) through a public tender process held more than one year before the start of the study.

All participants were instructed not to change their routine regarding equipment use and maintenance. The researchers recollected each respirator at the end of that same shift at the hospitalization units. Each of the professionals then received a new mask at the start of the second shift, that is: for another 5,15 and/or 30 consecutive days, starting to count immediately as from the current shift.

In other words, during the study, four respirators were sequentially distributed to all participating nursing assistants, who were responsible for their equipment during each of the following periods:

- $1^{\text {st }}$ period: the first $N 95$ respirator was distributed and collected (at the end of the shift) on the same first day;

- $2^{\text {nd }}$ period: each participant received a new respirator on the second shift day, collected after five calendar days;

- $3^{\text {rd }}$ period: after returning the second respirator, the next day, the third device was distributed for each participant to take care of during the next 15 days;

- $4^{\text {th }}$ period: at the end of the third period, each participant received the fourth and final respirator at the start of the next day, to take care of during the next 30 days.

The researchers took care to provide the respirators to the respective nursing assistants, nominally respecting each professional's shift scale. 
All collected respirators were subject to standardized assessment by one of the authors (LRPD), using a portable magnifying lens (2x), making notes on identification marks, folds, stains and internal and external dirt (characterizing the type of dirt and approximate surface percentage affected, using multiples of $25 \%)$. All findings were registered on individual forms (one for each participant) especially developed for this purpose.

Participants were allowed to replace their respirator at any time and for any reason, even if the four pre-established study periods were not respected. In this case, the counting of how many days that mask was used restarted as from the replacement day. The descriptive percentage presented below always considered the number of masks actually collected during the period in the denominator.

For statistical analysis, the chi-square test was used for comparisons between 6 and 12-hour shifts, with significance set at $5 \%(p<0.05 \%)$. The study complies with Resolution 196/96 and approval was obtained from the IIER Research Ethics Committee (opinion No 085/2005) and the institution's Scientific Committee.

\section{RESULTS}

The study included 167 nursing assistants, 144 of whom were women (86.23\%) and 23 men (13.77\%). Twenty-one (12.57\%) worked 6-hour shifts and 146 (87.43\%) 12-hour shifts; 115 (68.87\%) exclusively worked day shifts and 52 (31.13\%) night shifts. Work time at the IIER ranged from two months to 33 years. All nursing assistants indicated that they received instructions on the use of the N95 respirators when they were admitted and/or during recycling courses promoted by the institution's permanent education sector.

In total, 668 respirators were distributed according to the study method. Many masks were not returned as combined though - always in function of the alleged loss of the IPE (Table 1$)$. Only five $(0.75 \%)$ of these respirators were replaced outside the pre-established study periods, upon the participating professionals' requests.

Table 1 - Number of collected masks in function of the number of distributed masks during the pre-established study periods, Instituto de Infectologia Emílio Ribas - São Paulo - 2005

\begin{tabular}{lccr}
\hline & $\begin{array}{c}\text { Distributed } \\
\text { Masks }\end{array}$ & $\begin{array}{c}\text { Collected } \\
\text { Masks }\end{array}$ & $\%$ \\
\hline Period 1 & 167 & 167 & 100.00 \\
Period 2 & $167+1$ replaced & 140 & 83.83 \\
Period 3 & $167+3$ replaced & 122 & 73.05 \\
Period 4 & $167+1$ replaced & 102 & 61.08 \\
\hline Total & $668+5$ replaced & 531 & 79.49 \\
\hline
\end{tabular}

Obs: Period 1: one day; Period 2: five days; Period 3: 15 days; Period 4: 30 days.
The first observation of the returned respirators' physical structure referred to personal identification marks each professional made on his/her own equipment. These marks were usually made with a ballpoint pen, on both sides (internal and external) of the respirator, and generally indicated the user's initials or nickname. Some of these marks were visibly exaggerated, obviously caused structural damage and potentially compromised the device's filtering functions. One example of these identification marks and another of a well-defined fold can be observed in Figure 1.

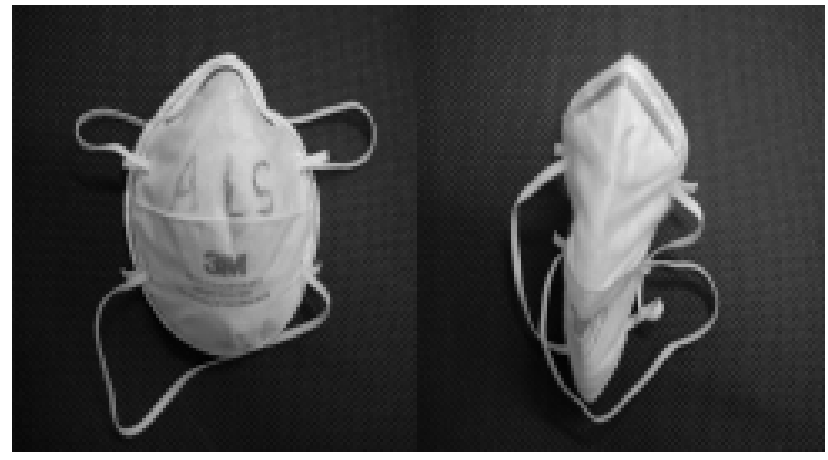

Figure 1 - Examples of masks collected after five days of use, one with exaggerated identification marks and another with a welldefined longitudinal fold, Instituto de Infectologia Emílio Ribas São Paulo - 2005

Figure 2 demonstrates the percentages of respirators with identification marks in function of their collection day. Not statistically significant differences were found between the presence of these marks made by 6 -hour and by 12 hour shift workers.

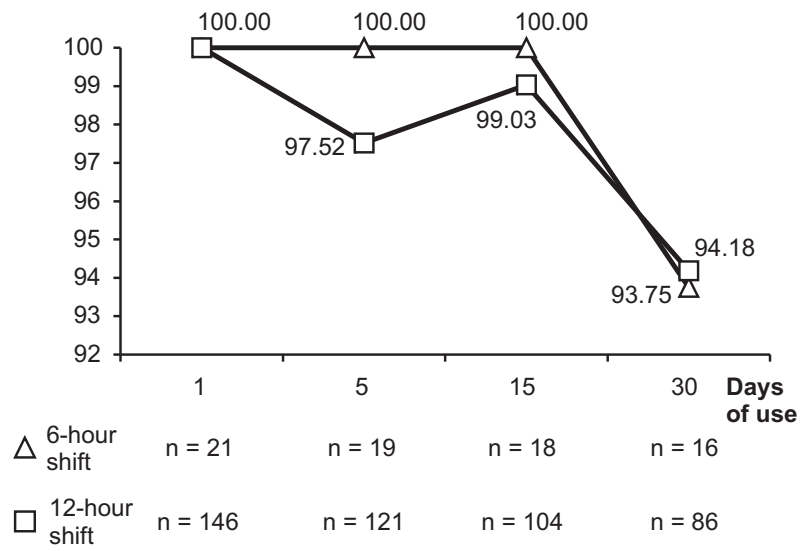

Figure 2 - Percentages of identification marks on masks collected after use by nursing assistants, per 6 or 12 -hour shift ( $p>0.05$ ), Instituto de Infectologia Emílio Ribas - São Paulo - 2005

Figure 3 illustrates that, after the first usage day, a relatively small quantity of respirators with well-defined folds was found, especially after 6-hour shifts. As from 15 days of use, however, absolutely all returned N95 respirators showed vertical, horizontal or lateral folds. The comparison between the respirators used by 6 -hour and 12 -hour 
shift workers revealed a statistically significant difference, with folds more frequently found in the IPE of 12-hour shift workers $(p<0.05)$.

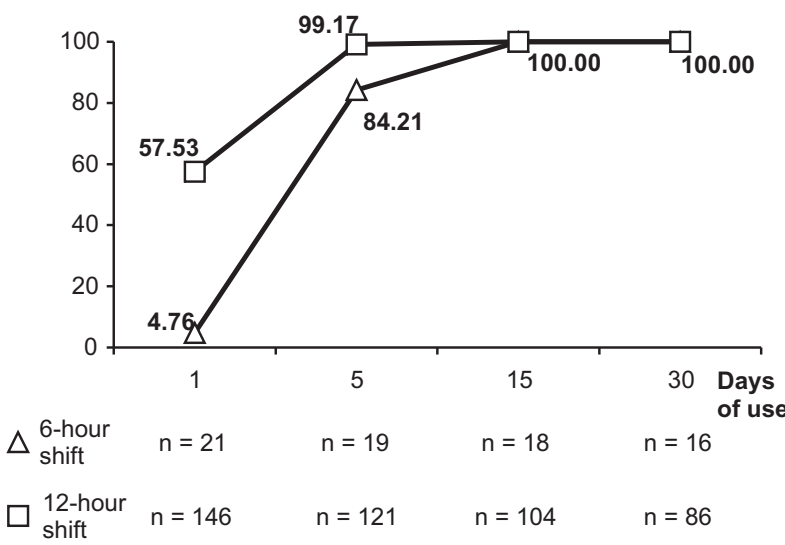

Figure 3 - Percentages of folds identified in masks collected after use by nursing assistants per 6 or 12 -hour shift $(p<0.05)$, Instituto de Infectologia Emílio Ribas - São Paulo - 2005

Another item that was observed was the presence of stains and dirt (visible to the naked eye) on the respirator walls. The internal side was more affected than the external side, directly related to the time of use (Figure 4). PFF2 masks used by 12-hour shift workers showed more internal dirt and stains than 6 -hour shift workers $(p<0.05)$. It should be highlighted that, as from the fifth day of use, all respirators showed some type of dirt or stain, covering between 25 and $50 \%$ of their surface.

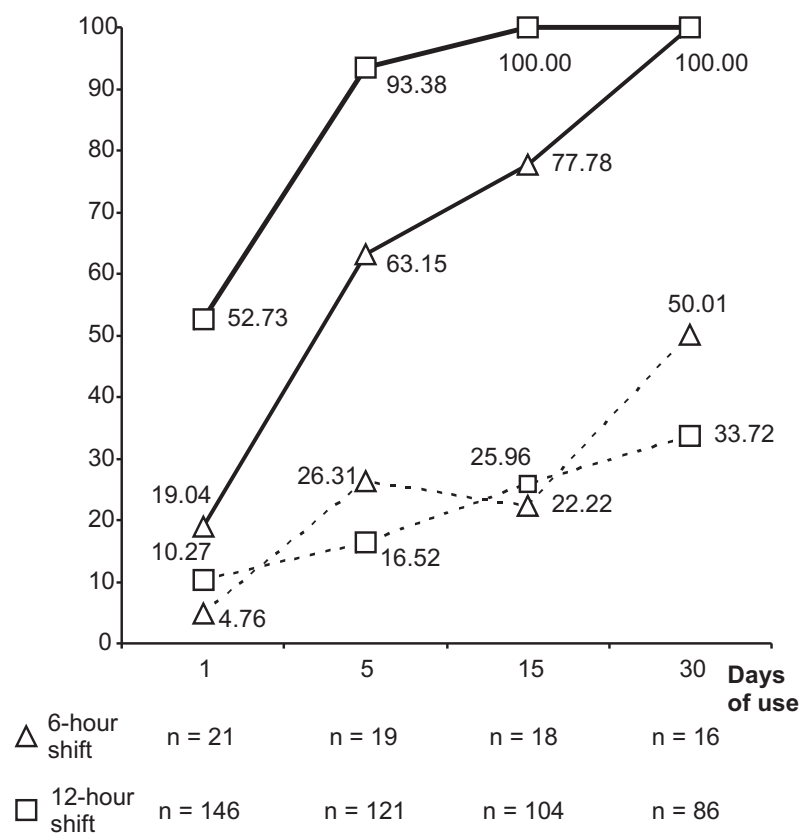

Figure 4 - Percentages of internal $(\mathrm{p}<0.05)$ and external dirt $(\mathrm{p}>0.05)$ on masks collected after use by nursing assistants per 6 or 12-hour shift, Instituto de Infectologia Emílio Ribas - São Paulo - 2005

Among the types of stains and dirt found included, make-up traces (especially lipstick marks) were the most frequent, besides some yellowish or blackened marks of unknown origin, skin appendages etc. The most frequent external dirt types were coffee stains and pen scribbles.

\section{DISCUSSION}

The dissemination of institutional TB represents a substantial occupational and public threat. The professional risk of catching nosocomial tuberculosis depends on a range of factors, including frequency, duration and intensity of exposure, besides the professional function and work place. According to $\mathrm{CDC}$ guidelines ${ }^{(1)}$, all people (including health workers and visitors) entering rooms with suspected TB patients or confirmed TB patients in isolation need to use respiratory IPE, that is, the $\mathrm{N} 95$ respirator.

The nursing team is the largest category of health professionals and, due to the nature of their tasks, they have the closest physical contact with the patients, through direct care functions like bathing, cleaning fluids and secretions, collecting biological samples etc. Hence, the nursing team is the professional group most exposed to occupational risk, including the risk of catching nosocomial tuberculosis.

Although nursing assistants perform their functions under direct supervision, a clear gap exists in acceptance of and adherence to preventive biosafety recommendations, including the use of $\mathrm{N} 95$ respirators. These professionals' socalled "experience" is frequently used as an argument to grant them a false feeling of self-protection and self-sufficiency, with IPE often being considered unnecessary and superfluous ${ }^{(7)}$. Another argument against the use of N95 respirators is related to the discomfort of the equipment itself $f^{(7-9)}$. Some foreign studies have appointed low adherence levels to the use of N95 masks (ranging from 30\% to 50\%), even in highrisk situations, such as procedures involving airway manipulation or in more susceptible hospital sectors, such as respiratory isolation wards ${ }^{(10-11)}$. The high percentage of misplaced respirators in this research, reaching almost 30\% after 15 days of use (Table 1) reinforces the feeling of lack of interest in the use of this equipment. By the way, very few participants requested the replacement of their misplaced mask.

The large number of folds found, as demonstrated in Figure 3, easily demonstrates difficulties to store the N95 respirator when it is not being used, on the other hand. The size and shape (cone) of this mask type do no allow users to guard them in the pocket of their clothes or apron. The presence of folds in the mask not only deforms the equipment structure and thus puts its filtering function at risk, but also makes it more difficult to fit the respirator to the user's face, as recommended. Other not cone but duck mouth-shaped N95 masks exist. Manufacturers designed these models with "original" folds already included and consider they are easier to store. These duck mouth masks are subjective and generically considered less uncomfortable and tend to cause less difficulties for their users' visual and oral communication. They seem to be less resistant though, and need to be replaced more frequently ${ }^{(12)}$. 
No study was found, however, which compared both models in clinical practice.

At the IIER, neither rules nor standards exist on the storage of the $\mathrm{N} 95$ respirator in a safe and organized place, like a cupboard or a line reserved especially for this purpose. Some wards chose to use a cardboard box where the IPE are stored, each inside a plastic bag. Some authors criticize this procedure because it facilitates humidity retention and growth of bacteria or fungi in the respirator ${ }^{(13-14)}$.

Another underestimated problem in this context is how each user identifies his/her IPE - being able to distinguish it from the equipment of colleagues working at the same unit can mean a hard task. As the present study method included the orientation that professionals should maintain their routine, the so frequent finding of subtle or exaggerated identification marks made with a ballpoint pen should be taken into account, due to the evident risk that this procedure will damage the device's fibers and filtering capacity. A simple solution to replace this type of conduct would be for the manufacturer to provide a small label, linked to the mask's elastic strap, with sufficient space for users to write their name or initials.

The presence of dirt (especially stains) on the mask walls is a natural consequence of their use - what should be considered is the degree of obstruction the dirt provokes in the equipment. In this case, however, this is not about questioning the loss of the respirator's filtering capacity, but the discomfort the user may feel to breathe. This difficulty is generally attributed to the equipment itself and not to the dirt that may exist, once again strengthening the idea that N95 masks are extremely uncomfortable.

Health institutions have to develop prevention and protection programs to deal with occupational risks. Therefore, it is essential for those responsible for purchasing IPE to select adequate products compatible with as many users as possible (independently of gender, age, weight, body structure etc.), also taking into account other variables like comfort and, obviously, financial cost ${ }^{(2,15)}$. The so-called fit testing of IPE on each user, although obligatory in the United States, is performed neither in Brazil nor in several other countries ${ }^{(16)}$.

The IIER represents a particular and singular reality, due to the fact that its workers (especially nursing auxiliaries) are almost constantly exposed to the nosocomial risk of catching tuberculosis (not to mention other less frequent but contagious diseases, such as meningococcal meningitis, hantavirus and other emerging viral infections, or even the recent epidemic provoked by the Influenza A H1N1 virus). In most hospitals (in Brazil and in other countries), health professionals use N95 respirators sporadically and individually, entering a nursing ward in respiratory isolation practically once per day ${ }^{(17)}$. In this case, masks tend to be immediately discarded after their use. This alone represents a higher financial cost (although the unit cost of each piece is less than half a US dollar), which certainly is not perceptible for generalist care institutions. These do not attend to a large infectious disease demand and their patients are in clinical and diagnostic conditions that have little effect on the use of these respirators. In the public health context, however, the costs of single-use discardable N95 masks cannot be underestimated. In the case of the IIER, for example, considering the number of professionals active in direct patient care, the estimated budget would increase by about 4,000 US\$ per month. Hence, reusing the respirators represents a justified and acceptable alternative, provided that it is viable and safe.

\section{CONCLUSION}

These study results may not be very surprising and perhaps do not differ from the simple collective impression left by clinical practice. Nevertheless, they indicate that, if the situation and facts observed here are maintained, each N95 respirator should be exclusive for use during a work shift of 12 hours at most or, if its reuse is absolutely necessary, the expiry date of five days should be respected.

Some facilities could already be put in practice, such as the abovementioned identification labels, the indication of specific IPE storage sites when not in use and frequent training, including recycling and permanent education classes. It should be highlighted though, that masks and respirators alone cannot be considered an efficient tuberculosis control means and do not justify any amount of investment if not associated with adequate diagnosis and treatment, besides other equally fundamental administrative and environmental measures.

\section{REFERENCES}

1. Jensen PA, Lambert LA, lademarco MF, Ridzon R, Centers for Disease Control and Prevention (CDC). Guidelines for preventing the transmission of Mycobacterium tuberculosis in health care settings, 2005. MMWR Recomm Rep. 2005;54(RR-17):1-141.

2. Centers for Disease Control and Prevention (CDC). Laboratory performance evaluation of N95 facepiece respirators, 1996. MMWR Morb Mortal Wkly Rep. 1998;47(48):1045-9.
3. Fennelly KP. Personal respiratory protection against Mycobacterium tuberculosis. Clin Chest Med. 1997;18(1):1-17.

4. Brasil. Ministério do Trabalho e Emprego. Norma Regulamentadora NR 6 - Equipamentos de Proteção Individual - EPI [legislação na Internet]. Brasília; 2006. [citado 2007 fev. 12]. Disponível em: http://www.mte.gov.br/legislacao/normas_regulamentadoras/ nr_06.pdf 
5. 3M Company. Reusable respirator facepieces and powered air purifying respirator systems (PAPRs) in the health care environment: considerations for use. Technical Data Bulletim \#160. St. Paul, Minnesota; 2003. p. 1-6.

6. Rengasamy A, Zhuang Z, BerryAnn R. Respiratory protection against bioaerosols: literature review and research needs. Am J Infect Control. 2004;32(6):345-54.

7. Nishide VM, Benatti MCC. Riscos ocupacionais entre trabalhadores de enfermagem de uma unidade de terapia intensiva. Rev Esc Enferm USP. 2004;38(4):406-14.

8. Foo CC, Goon AT, Leow YH, Goh CL. Adverse skin reactions to personal protective equipment against severe acute respiratory syndrome: a descriptive study in Singapore. Contact Dermatitis. 2006;55(5):291-4.

9. Lim EC, Seet RC, Lee KH, Wilder-Smith EP, Chuah BY, Ong BK. Headaches and the $\mathrm{N} 95$ face-mask among healthcare providers. Acta Neurol Scand. 2006;113(3):199-202.

10. Biscotto CR, Pedroso ER, Starling CE, Roth VR. Evaluation of N95 respirator use as a tuberculosis control measure in a resourcelimited setting. Int J Tuberc Lung Dis. 2005;9(5):545-9.

11. Luksamijarulkul P, Supapvanit $C$, Loosereewanich $P$, Aiumlaor P. Risk assessment towards tuberculosis among hospital personnel: administrative control, risk exposure, use of protective barriers and microbial air quality. Southeast Asian J Trop Med Public Health. 2004;35(4):1005-11.
12. Fennely KP. The role of masks in preventing nosocomial transmission of tuberculosis. Int J Tuberc Lung Dis. 1998;2 (9):S103-9.

13. Pasanen AL, Keinanan J, Kalliokoski P, Martikainen P, Ruuskanen J. Microbial growth on respirator filters from improper storage. Scand J Work Environ Health. 1993;19(6):421-5.

14. Reponen TA, Wang Z, Willeke K, Grinshpun SA. Survival of mycobacteria on $\mathrm{N} 95$ personal respirators. Infect Control Hosp Epidemiol. 1999;20(4):237-41.

15. Lee K, Slavcev A, Nicas M. Respiratory protection against Mycobacterium tuberculosis: quantitative fit test outcomes for five type $\mathrm{N} 95$ filtering-facepiece respirators. J Occup Environ Hyg. 2004;1(1):22-8.

16. Hong SW. Preventing nosocomial Mycobacterium tuberculosis transmission in international settings. Emerg Infect Dis. 2001;7(2):245-8.

17. World Health Organization (WHO). Addendum to the Guidelines for the Prevention in Health Care Facilities in Resource-Limited Settings. Geneva; 2006. (WHO/TB/99.269).
Correspondence addressed to: Ricardo $\mathrm{H}$. Bammann Al. Ministro Rocha Azevedo, 373 - Apto. 82C CEP 01410-001- São Paulo, SP, Brazil 